\title{
Recovery of Stored Aerobic Granular Sludge and Its Contaminants Removal Efficiency under Different Operation Conditions
}

\author{
Zhiwei Zhao, ${ }^{1}$ Shuo Wang, ${ }^{1,2}$ Wenxin Shi, ${ }^{1}$ and $\mathrm{Ji} \mathrm{Li}^{2}$ \\ ${ }^{1}$ State Key Laboratory of Urban Water Resource and Environment, Harbin Institute of Technology, Harbin 150090, China \\ ${ }^{2}$ School of Environment and Civil Engineering, Jiangnan University, Wuxi 214122, China \\ Correspondence should be addressed to Wenxin Shi; swx@hit.edu.cn
}

Received 17 May 2013; Accepted 27 June 2013

Academic Editor: José Manuel Domínguez González

Copyright (c) 2013 Zhiwei Zhao et al. This is an open access article distributed under the Creative Commons Attribution License, which permits unrestricted use, distribution, and reproduction in any medium, provided the original work is properly cited.

\begin{abstract}
The quick recovery process of contaminants removal of aerobic granular sludge (AGS) is complex, and the influencing factors are still not clear. The effects of dissolved oxygen (DO, air intensive aeration rate), organic loading rate (OLR), and C/N on contaminants removal characteristics of AGS and subsequently long-term operation of AGS bioreactor were investigated in this study. DO had a major impact on the recovery of AGS. The granules reactivated at air intensive aeration rate of $100 \mathrm{~L} / \mathrm{h}$ achieved better settling property and contaminants removal efficiency. Moreover, protein content in extracellular polymeric substance (EPS) was almost unchanged, which demonstrated that an aeration rate of $100 \mathrm{~L} / \mathrm{h}$ was more suitable for maintaining the biomass and the structure of AGS. Higher OLR caused polysaccharides content increase in EPS, and unstable C/N resulted in the overgrowth of filamentous bacteria, which presented worse $\mathrm{NH}_{4}^{+}-\mathrm{N}$ and $\mathrm{PO}_{4}^{3-}-\mathrm{P}$ removal. Correspondingly, quick recovery of contaminants removal was accomplished in 12 days at the optimized operation conditions of aeration rate $100 \mathrm{~L} / \mathrm{h}$, OLR $4 \mathrm{~g} / \mathrm{L} \cdot \mathrm{d}$, and C/N $100: 10$, with COD, $\mathrm{NH}_{4}^{+}-\mathrm{N}$, and $\mathrm{PO}_{4}^{3-}-\mathrm{P}$ removal efficiencies of $87.2 \%, 86.9 \%$, and $86.5 \%$, respectively. The renovation of AGS could be successfully utilized as the seed sludge for the rapid start-up of AGS bioreactor.
\end{abstract}

\section{Introduction}

Aerobic granular sludge (AGS) was considered to be a special kind of biofilm structure composing of self-immobilized cells $[1,2]$. With regular shape, smooth surface, and compact and strong microbial structure, AGS has the advantages of better settling property, lower consuming, higher biomass retention, and treatment efficiency than normal activated sludge $[3,4]$. Therefore, AGS has been proposed as a promising technology which could be widely applied in the treatment of high organic wastewater [5] and wastewater with toxic components [6] as well as wastewater with toxicity and heavy metal $[7,8]$. AGS technology possesses the ability to contribute to and improve the biological treatment of wastewater. Compared to normal wastewater treatment plants, similar efficiencies at lower costs could be achieved with the compact AGS technology [9].

Microbial forces by extracellular polymeric substances (EPS) were regarded as the significant factor in the formation process of AGS [10]. Protein content in EPS, rather than polysaccharides, was enriched in AGS [11, 12] which was known as the key component of EPS. It is believed that high protein content and relatively high PN/PS (the ratio of protein content and polysaccharides content in EPS) ratio would be a good situation to keep stable internal microstructure and high biomass retention. Enrichment of EPS assisted granulation, enhanced granules stability, which is important during the operation of AGS bioreactor, and reduced the loss of granules in storage [1].

However, AGS would lose its microbial activity under extended idle conditions or after long-term storage, which is one of the main problems hindering the practical application of AGS technology [13]. In addition, the cultivation of AGS, quick start-up, and stable operation of AGS bioreactor restricted the development of AGS technology, from lab scale to pilot scale as well [12]. Consequently, the longterm storage and quick recovery of contaminants removal of AGS are remarkably important for its full-scale application. 
TABLE 1: Physical parameters of AGS before and after storage.

\begin{tabular}{lcccccc}
\hline & \multicolumn{5}{c}{ Physical parameters } \\
& SVI $(\mathrm{mL} / \mathrm{g})$ & MLSS $(\mathrm{mg} / \mathrm{L})$ & MLVSS $(\mathrm{mg} / \mathrm{L})$ & MLVSS/MLSS $(\%)$ & $\rho\left(\mathrm{g} / \mathrm{cm}^{3}\right)$ & Diameter $(\mathrm{mm})$ \\
\hline Before storage & 49.3 & 8.45 & 7.73 & 91.5 & 1.040 & 2.8 \\
After storage & 64.1 & 8.45 & 7.25 & 85.8 & 1.032 & 2.6 \\
\hline
\end{tabular}

The storage of AGS, including the bioactivity preservation and physical characteristics maintenance, was influenced by $\mathrm{DO}, \mathrm{OLR}$, and $\mathrm{C} / \mathrm{N}[1,14]$. Moreover, the rapid recovery of contaminants removal and subsequent quick start-up of AGS bioreactor were also controlled by such factors.

In order to improve the flexibility and enhance the practicability of AGS technology, this study investigated the effects of DO, OLR, and C/N on the settling property, EPS, and microbial activity of AGS, and further to explore optimal operation conditions on contaminants removal.

\section{Materials and Methods}

2.1. Aerobic Granular Sludge Cultivation. The experiment was carried out in a sequencing batch airlift reactor (SBAR). The working volume of the reactor is $5.4 \mathrm{~L}$, with a height of $100 \mathrm{~cm}$ and an internal diameter of $10 \mathrm{~cm}$. The internal riser pipeline was $70 \mathrm{~cm}$ in height, $6 \mathrm{~cm}$ in internal diameter, and $2 \mathrm{~cm}$ leaving the bottom. Compressed air was supplied via a diffuser at the bottom of the reactor with a flux of $120 \mathrm{~L} / \mathrm{h}$. Effluent was discharged from the middle port of the reactor with a volumetric exchange ratio of $50 \%$. The operating cycle time was $6 \mathrm{~h}$, including $30 \mathrm{~min}$ for idle, $30 \mathrm{~min}$ for static feeding, $5 \mathrm{~min}$ for settling, $5 \mathrm{~min}$ for effluent discharge, and the rest of the time for aeration. Accordingly, the temperature of the mixed liquid was kept at ambient temperature, and influent $\mathrm{pH}$ and solids retention time (SRT) were adjusted to $7.0-7.2$ (by $1 \mathrm{~mol} / \mathrm{L} \mathrm{HCl}$ and $1 \mathrm{~mol} / \mathrm{L} \mathrm{NaOH}$ ) and 30 days, respectively.

2.2. Synthetic Wastewater and Seed Sludge. The components and concentrations in synthetic wastewater were listed as (mg/L) $\mathrm{NaAc} 830.0, \mathrm{CaCl}_{2}$ 60.0, $\mathrm{MgSO}_{4} 42.0, \mathrm{NH}_{4} \mathrm{Cl} 240.0$, EDTA 42.0, $\mathrm{NaHCO}_{3}$ 250.0, and $\mathrm{K}_{2} \mathrm{HPO}_{4}$ 58.0, $\mathrm{KH}_{2} \mathrm{PO}_{4}$ 24.0 [14], in element solution $1 \mathrm{~mL}$, which gave a total COD concentration of $1200 \mathrm{mg} / \mathrm{L}$; the concentration of $\mathrm{NH}_{4}{ }^{+}-\mathrm{N}$ was $60 \mathrm{mg} / \mathrm{L}$, and the concentration of $\mathrm{PO}_{4}{ }^{3-}-\mathrm{P}$ with $16 \mathrm{mg} / \mathrm{L}$. Trace element solution contained the following components (g/L): $\mathrm{FeCl}_{3} \cdot 6 \mathrm{H}_{2} \mathrm{O} 1.5, \mathrm{H}_{3} \mathrm{BO}_{3} 0.15, \mathrm{CuSO}_{4} \cdot 5 \mathrm{H}_{2} \mathrm{O} 0.03, \mathrm{KI}$ $0.03, \mathrm{MnCl}_{2} \cdot 4 \mathrm{H}_{2} \mathrm{O} 0.12, \mathrm{Na}_{2} \mathrm{MoO}_{4} \cdot 2 \mathrm{H}_{2} \mathrm{O} 0.06, \mathrm{ZnSO}_{4} \cdot 7 \mathrm{H}_{2} \mathrm{O}$ 0.12 , and $\mathrm{CoCl}_{2} \cdot 6 \mathrm{H}_{2} \mathrm{O} 0.15$ [15]. The seed activated sludge was taken from the aerobic tank of Wenchang wastewater treatment plant (WWTP in Harbin, China) with an anoxic/oxic process (A/O process).

2.3. Storage and Recovery of Aerobic Granular Sludge. The inoculated AGS had been stored at a $4^{\circ} \mathrm{C}$ refrigerator for more than 6 months and then regained in the previously mentioned SBAR after washing by distilled water for 3 times, with the same operation conditions and synthetic wastewater components in different reactors. The temperature of the mixed liquid was kept at ambient temperature, and influent $\mathrm{pH}$ was adjusted to 7.0-7.2. DO (Do concentration was represented by air intensive aeration rate, 50, 100, 150, and $200 \mathrm{~L} / \mathrm{h})$, OLR (2, 4, 8 and $16 \mathrm{~g} / \mathrm{L} \cdot \mathrm{d})$, and C/N (100:5, $100: 10$, and $100: 20)$ were regulated and controlled to investigate the recovery on contaminants removal characteristics.

2.4. Analysis Methods. $\mathrm{COD}, \mathrm{NH}_{4}{ }^{+}-\mathrm{N}, \mathrm{NO}_{2}{ }^{-}-\mathrm{N}, \mathrm{NO}_{3}{ }^{-}-\mathrm{N}$, $\mathrm{PO}_{4}{ }^{3-}$ - $\mathrm{P}$, mixed liquor suspended solids (MLSS), and mixed liquor volatile suspended solids (MLVSS) were analyzed according to the Standard Method [16]. Granules size and wet density were determined according to the methods by Laguna et al. and Schwarzenbeck et al. [17, 18]. The microstructure and morphology of the AGS were observed by scanning electron microscope (SEM, S-4800N, Japan). Sludge volume index (SVI) was determined according to the settled bed volume after $30 \mathrm{~min}$ settling and the dry biomass weight [14]. The extraction of EPS was performed by the usage of ultrasound-formamide- $\mathrm{NaOH}$ method [1]. Total polysaccharides (PS) and total protein (PN) contents in EPS were quantified by Dubois et al. and Lowry et al. [19, 20].

\section{Results and Discussion}

3.1. Storage of Aerobic Granular Sludge. Mature AGS cultivated in the SBAR was kept at a $4^{\circ} \mathrm{C}$ refrigerator, and $\mathrm{pH}$ was adjusted to 7.0-7.2; especially, the feed liquid was replaced every two weeks. The morphology and integrity of AGS were both in good condition after 6 months of storage. The physical parameters were listed in Table 1. Granules size and wet density were basically unchanged after storage; however, AGS had apparent variation in its biomass and settling property. Biomass retention decreased from 7.73 to $7.25 \mathrm{mg} / \mathrm{L}$, probably due to the release of soluble organic material and cell hydrolysis as reported by Tay et al. [21]. After 6 months of storage, its settling property deteriorated as shown from the values of SVI. SVI obviously increased from 49.3 to $64.1 \mathrm{~mL} / \mathrm{g}$, indicating that granules cannot maintain better settling property after long-term storage.

3.2. Recovery of Contaminants Removal Efficiency. AGS after the 6-month storage was utilized as the seed sludge for the quick start-up of the SBAR. Before the seeding, the granules taken from the $4^{\circ} \mathrm{C}$ refrigerator should be washed for three times to remove the fermentation products and the residual nutrient substances. 


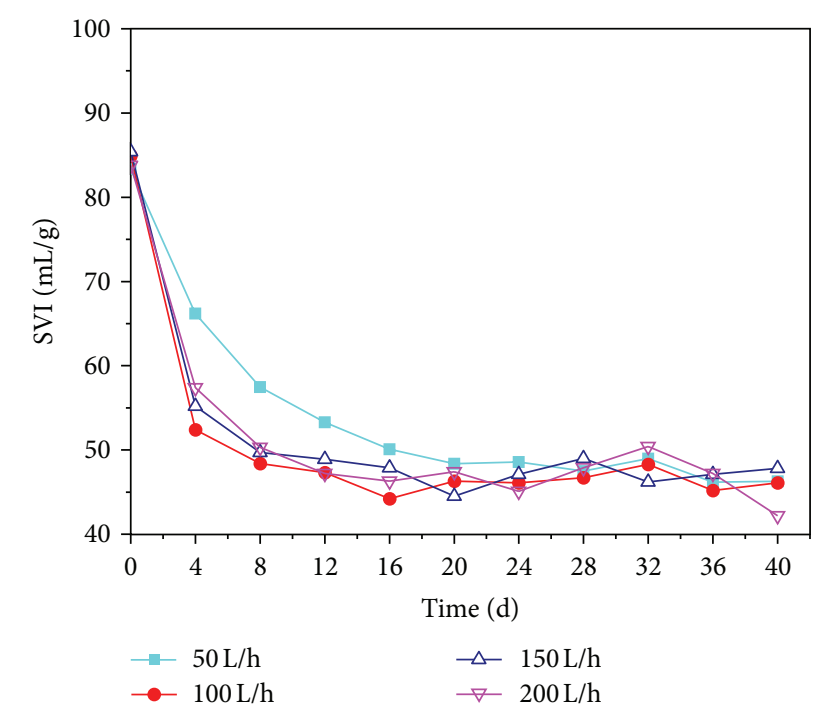

FIGURE 1: Variations of SVI at different air intensive aeration rates.

\subsubsection{DO (Air Intensive Aeration Rate)}

Effects of DO on the Settling Property. As shown in Figure 1, AGS had good settling property in the reactivation process. SVI of the granules decreased obviously in the first 8 days, and the granules had faster decline rate at the air intensive aeration rates of 100,150 and $200 \mathrm{~L} / \mathrm{h}$ than $50 \mathrm{~L} / \mathrm{h}$. The SVI of AGS decreased to $57.5,48.4,49.7$, and $50.3 \mathrm{~mL} / \mathrm{g}$ at the 8 th day; then, it was maintained at a low level indicating their excellent settling ability. The granules revived under different air intensive aeration rates $(100,150$, and $200 \mathrm{~L} / \mathrm{h})$ obtained quick recovery on its settle capacity. The SVI of granules reactivated at air intensive aeration rate of $100 \mathrm{~L} / \mathrm{h}$ varied from 84.9 to $46.1 \mathrm{~mL} / \mathrm{g}$, which demonstrated that he granules had better settling property. In addition, relatively low air intensive aeration rate could be more economic and conductive for large-scale production and practical application. Therefore, $100 \mathrm{~L} / \mathrm{h}$ aeration rate is good in the recovery of settling property.

Effects of DO on Granules Structure. Bacterium can secrete sticky materials called EPS constituting proteins (PN), polysaccharides (PS), humic acids, and lipids, which could assist cell adhesion; thereby, it should be helpful to initiate the aerobic granulation process [12] (Schmidt et al., 2004). Protein and polysaccharides contents in EPS of AGS before the 6 months of storage were visually the same as those after the storage, with PN content of $80.3 \mathrm{mg} / \mathrm{gMLSS}$ and PS content of $27.0 \mathrm{mg} / \mathrm{gMLSS}$. The ratio of PN/PS was 3.0. As illustrated in Figure 2(a), protein content was basically unchanged, implying the stable internal structure of AGS. PN content in EPS of the granules was 78.4, 82.5, 80.3, and $82.4 \mathrm{mg} / \mathrm{gMLSS}$ under different air intensive aeration rates $(50,100,150$, and $200 \mathrm{~L} / \mathrm{h})$. However, PS content under different air intensive aeration rates changed a lot (Figure 2(b)). PS content in EPS declined from 27.0 to $14.3 \mathrm{mg} / \mathrm{gMLSS}$ at air intensive aeration rate of $50 \mathrm{~L} / \mathrm{h}$, while it declined to
37.9 and $43.1 \mathrm{mg} / \mathrm{gMLSS}$ at air intensive aeration rate of 150 and $200 \mathrm{~L} / \mathrm{h}$. The variation of PS content caused unsteady $\mathrm{PN} / \mathrm{PS}$ ratio and resulted in the fast disintegration of granules [13]. High PN content could be the cross-linked network by attraction of organic and inorganic materials [22] and the bridge of microbial cells once aerobic granules formed, which was consistent with the results of Adav et al. and Wang et al. $[23,24]$. The present findings indicate that the induction of coaggregation and intracellular interaction by EPS played a significant role in the formation and maintenance of AGS.

Effects of DO on Contaminants Removal. DO was an important factor influencing nitrification and denitrification, which also expressed the key effect on the phosphorus release in anaerobic phase and the phosphorus uptake in aerobic phase [14]. Therefore, $\mathrm{NH}_{4}{ }^{+}-\mathrm{N}$, and $\mathrm{PO}_{4}{ }^{3-}-\mathrm{P}$ removal efficiency would be greatly impacted by $\mathrm{DO}$. Before the storage, AGS possessed good COD, $\mathrm{NH}_{4}{ }^{+}-\mathrm{N}$ and $\mathrm{PO}_{4}{ }^{3-}$ $\mathrm{P}$ removal performance, with $\mathrm{COD}, \mathrm{NH}_{4}{ }^{+}-\mathrm{N}$, and $\mathrm{PO}_{4}{ }^{3-}-\mathrm{P}$ removal efficiency of $90.2 \%, 93.5 \%$, and $94.2 \%$, respectively. However, the granules bioactivity to remove contaminants decreased after the storage. Microbial activity of aerobic granules began to revive, and $\mathrm{NH}_{4}{ }^{+}-\mathrm{N}$ removal ability was enhanced with the recovery progress (Figure 3(a)). As can be seen in the figure, $\mathrm{NH}_{4}{ }^{+}-\mathrm{N}$ removal rates were kept increasing in the first 8 days, especially for the air intensive aeration rates of 100 and $150 \mathrm{~L} / \mathrm{h}$. While for the air intensive aeration rate of $200 \mathrm{~L} / \mathrm{h}$, the story was somehow different, $\mathrm{NH}_{4}{ }^{+}-\mathrm{N}$ removal rate increased in the first 4 days and then decreased after 20 days. After 20 days reactivation, $\mathrm{NH}_{4}{ }^{+}-\mathrm{N}$ removal accomplished high removal efficiency of $77.4 \%, 85.7 \%$, and $89.7 \%$ under aeration rates of 50,100 , and $150 \mathrm{~L} / \mathrm{h}$, which indicated that the granules gained better $\mathrm{NH}_{4}{ }^{+}-\mathrm{N}$ removal recovery performance. However, $\mathrm{NH}_{4}{ }^{+}-\mathrm{N}$ removal rate declined to $55.4 \%$ at the aeration rate of $200 \mathrm{~L} / \mathrm{h}$, probably because the sufficient oxygen supply led to the low bioactivity and slow specific growth rate of autotrophic bacteria including ammonia oxidized bacteria (AOB) and nitrite oxidized bacteria (NOB) $[25,26]$.

As displayed in Figure 3(b), the variations of $\mathrm{PO}_{4}{ }^{3-}-\mathrm{P}$ removal were basically the same and presented a good correlation with $\mathrm{NH}_{4}{ }^{+}-\mathrm{N}$ removal. $\mathrm{PO}_{4}{ }^{3-}$ - $\mathrm{P}$ removal efficiency of the granules that recovered at aeration rate of 100 and $150 \mathrm{~L} / \mathrm{h}$ increased up to $80 \%$ after activation for 16 days, which is higher than other recovery conditions. The granules had the characteristic of phosphorus accumulating potential with concomitant uptake of soluble organic carbon and release of phosphorus in the anaerobic stage, followed by rapid phosphorus uptake in the aerobic stage [27]. However, $\mathrm{PO}_{4}{ }^{3-}-\mathrm{P}$ removal of the granules that revived at an aeration rate of $200 \mathrm{~L} / \mathrm{h}$ reached its maximum and then obviously declined to $47.2 \%$. The result indicated that the sufficient oxygen supply might decrease the anaerobic zone inside AGS, which hindered the microbial activity of phosphorus accumulating organisms (PAO) and inhibited the phosphorus release and uptake process.

It is believed that the microstructure of the granules could be sustained and microbial activity retained good 


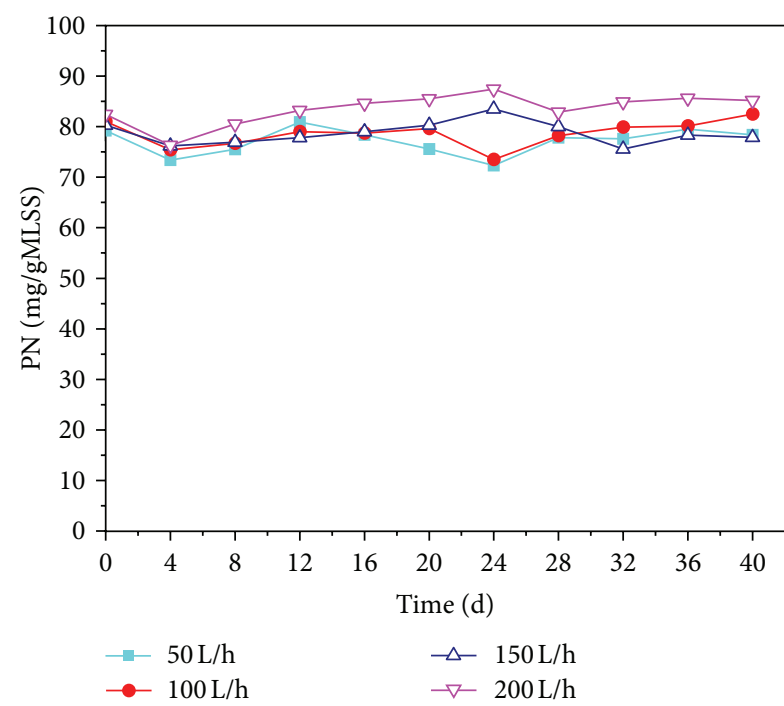

(a)

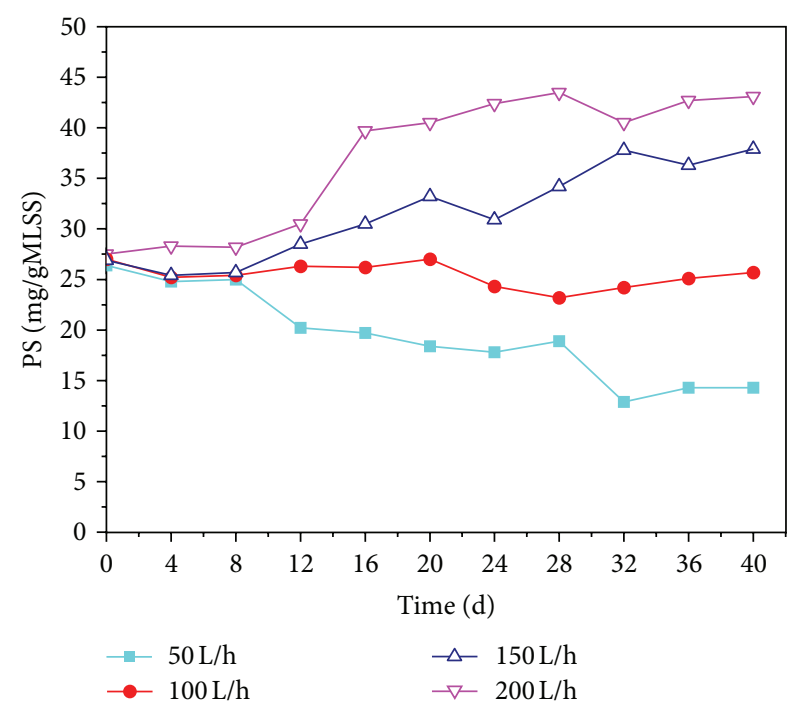

(b)

FIGURE 2: Variations of PN (a) and PS (b) contents in EPS at different air intensive aeration rates.

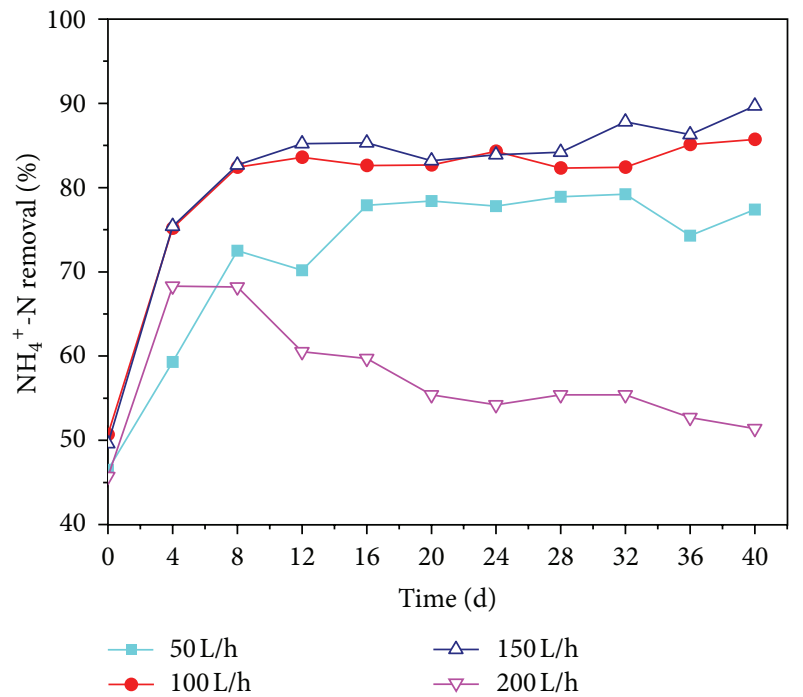

(a)

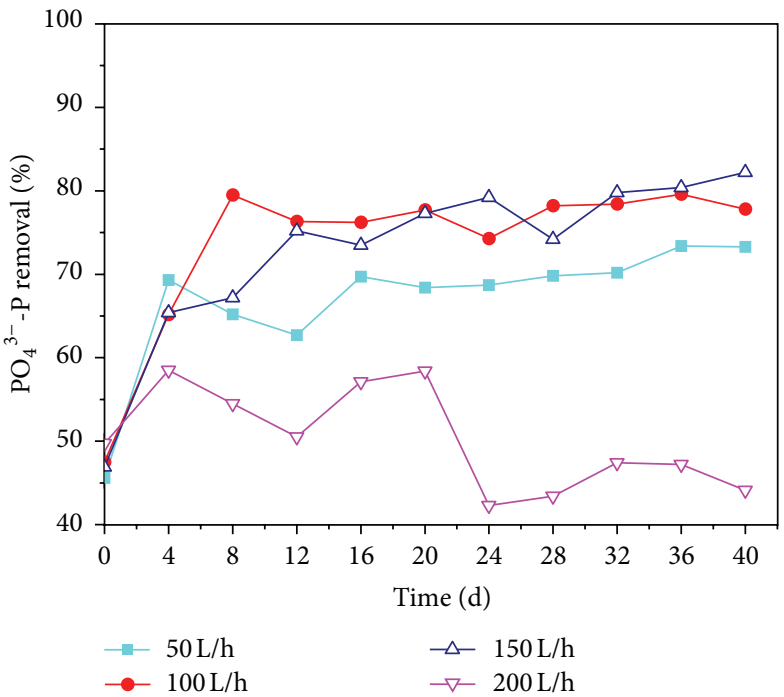

(b)

FIGURE 3: Variations of $\mathrm{NH}_{4}{ }^{+}-\mathrm{N}$ (a) and $\mathrm{PO}_{4}{ }^{3-}-\mathrm{P}(\mathrm{b})$ removal at different air intensive aeration rates.

performance. The results showed that DO had a major impact on the settling property and contaminants removal efficiency of AGS. In addition, protein content in EPS was almost unchanged, which demonstrated that air intensive aeration rate of $100 \mathrm{~L} / \mathrm{h}$ was more suitable for maintaining biomass and the structure of AGS.

\subsection{2. $O L R$}

Effects of OLR on Granules Structure. It is believed that high protein content and relatively high PN/PS ratio would be good in keeping stable internal microstructure and high biomass retention $[11,12]$. The variations of PN/PS ratio under different OLRs were illustrated in Figure 4. In the recovery process of AGS, PN and PS contents in EPS reactivated at 2 and $4 \mathrm{~g} / \mathrm{L} \cdot \mathrm{d}$ were almost unchanged which possessed the stable structure of the granules. However, high OLR had a great impact on the PN/PS ratio. The variations of PN/PS revived at 8 and $16 \mathrm{~g} / \mathrm{L} \cdot \mathrm{d}$ of OLR showed similar trend. PN content in EPS of AGS was stable, but PS content increased obviously, which were as high as 43.7 and $50.6 \mathrm{mg} / \mathrm{gMLSS}$, resulting in the PN/PS ratio remaining at the low level of 1.5. Hence, relatively high PS content in EPS could reduce the integration and stability of the granules; however, Costerton 


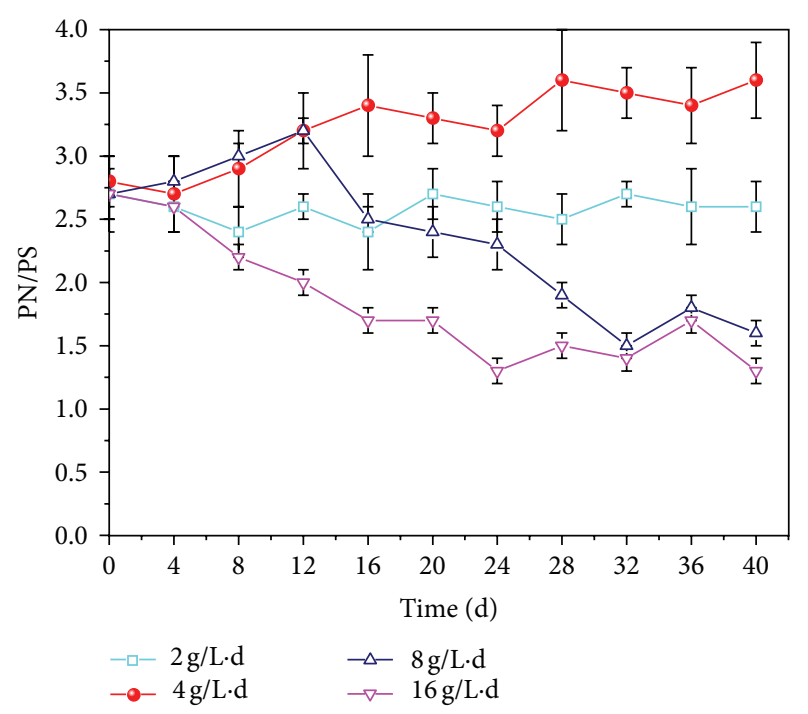

FIGURE 4: Variations of PN/PS ratio at different organic loading rates.

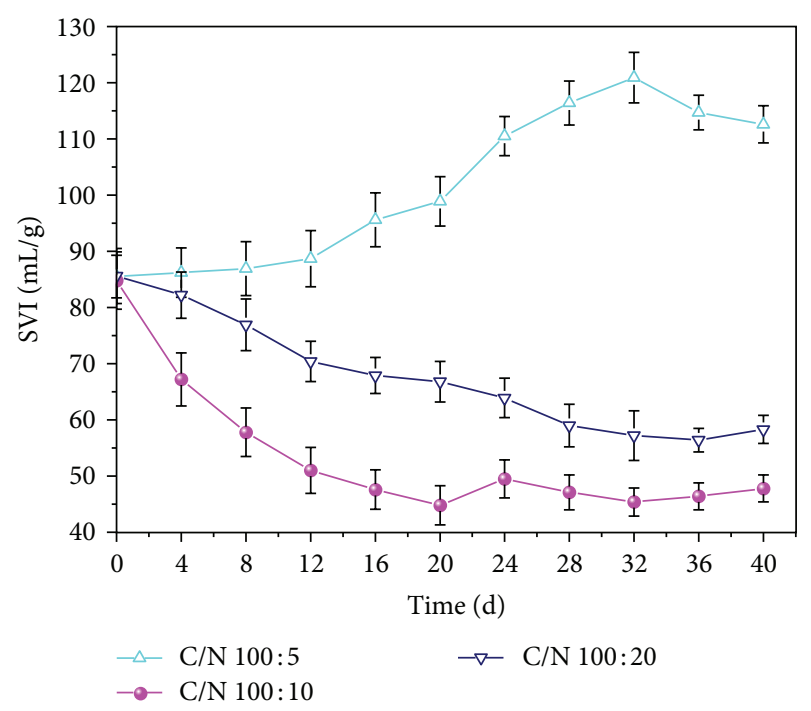

Figure 5: Variations of SVI at different $\mathrm{C} / \mathrm{N}$ ratio.

et al. and Tay et al. discovered that high PS content was noted to facilitate cell-to-cell adhesion and strengthen the structure of granules through a polymeric matrix $[28,29]$.

Effects of OLR on Contaminants Removal. AGS did not lose all the contaminants removal abilities after the 6-month storage. The concentrations of contaminants in the effluent of the SBAR and contaminants removal efficiency after 31 days reactivation were listed in Table 2 . COD removal efficiency reached about $80 \%$ under different organic loading rates in the first 8 days; then, COD removal was obtained at high efficiency of $89.2 \%, 89.4 \%, 90.5 \%$, and $94.4 \%$, respectively, which demonstrated good COD removal efficiency. Nonetheless,
$\mathrm{NH}_{4}{ }^{+}-\mathrm{N}$ and $\mathrm{PO}_{4}{ }^{3-}-\mathrm{P}$ removal was quite different; relatively high OLR conditions resulted in lower $\mathrm{NH}_{4}{ }^{+}-\mathrm{N}$ and $\mathrm{PO}_{4}{ }^{3-}-\mathrm{P}$ removal as a result of the disintegration and deterioration of AGS $[13,30]$. The granules revived under OLR of $4 \mathrm{~g} / \mathrm{L} \cdot \mathrm{d}$ gained good $\mathrm{NH}_{4}{ }^{+}-\mathrm{N}$ and $\mathrm{PO}_{4}{ }^{3-}$-P removal efficiency of $90.5 \%$ and $80.7 \%$.

The granules reactivated at OLR of $4 \mathrm{~g} / \mathrm{L} \cdot \mathrm{d}$ could maintain good structural integrity and high contaminants removal efficiency. Meanwhile along the recovery process, PS content in EPS was progressively increased which led to the disintegration of AGS and worse $\mathrm{NH}_{4}{ }^{+}-\mathrm{N}$ and $\mathrm{PO}_{4}{ }^{3-}-\mathrm{P}$ removal efficiency under higher OLR conditions. Therefore, AGS revived at OLR of $4 \mathrm{~g} / \mathrm{L} \cdot \mathrm{d}$ was more suitable for the long-term stable operation of AGS.

\subsection{3. $\mathrm{C} / \mathrm{N}$}

Effects of $C / N$ Ratio on the Settling Property of AGS. It is apparent in Figure 5 that low $\mathrm{C} / \mathrm{N}$ caused good settling property in the recovery process. SVI values were 47.8 and $57.2 \mathrm{~mL} / \mathrm{g}$ at $\mathrm{C} / \mathrm{N}$ of $100: 10$ and $100: 20$, respectively. The SVI of the granules that revived at C/N of $100: 10$ decreased significantly faster than that of the granules revived at $\mathrm{C} / \mathrm{N}$ of $100: 20$. However, the SVI of AGS reactivated at C/N of $100: 5$ obviously increased up to $110.5 \mathrm{~mL} / \mathrm{g}$ and then was retained at a high level that presented worse settling ability. The finding revealed that the compact AGS grew in size but gradually lost the stability corresponding with the outgrowth of filamentous bacteria. Therefore, unstable $\mathrm{C} / \mathrm{N}$ resulted in the overgrowth of filamentous bacteria, which presented worse contaminants removal efficiency $[14,31]$.

Effects of $\mathrm{C} / \mathrm{N}$ on Contaminants Removal Efficiency. Effluent contaminants and contaminants removal efficiency after 31 days reactivation were listed in Table 2. Along with restoration, $\mathrm{COD}$ removal efficiency under different $\mathrm{C} / \mathrm{N}$ conditions gained higher removal efficiency of $87.9 \%, 88.2 \%$, and $89.6 \%$, respectively, indicating excellent COD removal efficiency. Nevertheless, $\mathrm{NH}_{4}{ }^{+}-\mathrm{N}$ and $\mathrm{PO}_{4}{ }^{3-}-\mathrm{P}$ removal was quite distinct. $\mathrm{NH}_{4}{ }^{+}-\mathrm{N}$ removal efficiency at $\mathrm{C} / \mathrm{N}$ of $100: 5$ was $62.4 \%$ because heterotrophic bacteria, whose growth rate was faster than those in a lower $\mathrm{C} / \mathrm{N}$, would be in a competitive advantage in inhibiting the activity of nitrifying bacteria and autotrophic bacteria [25]. Furthermore, $\mathrm{PO}_{4}{ }^{3-}$ $\mathrm{P}$ removal efficiency at $\mathrm{C} / \mathrm{N}$ of $100: 20$ was $64.6 \%$ because of the competition of soluble organic carbon between PAOs and denitrifiers that hindered the microbial activity of PAOs [32]. The granules reactivated under $\mathrm{C} / \mathrm{N}$ of $100: 10$ achieved both good $\mathrm{NH}_{4}{ }^{+}-\mathrm{N}$ and $\mathrm{PO}_{4}{ }^{3-}-\mathrm{P}$ removal efficiencies of $88.2 \%$ and $89.1 \%$.

In this study, different $\mathrm{C} / \mathrm{N}$ conditions had significant impacts on the settling property of AGS during the reactivation process. High $\mathrm{C} / \mathrm{N}$ rate resulted in the overgrowth of filamentous bacteria, which presented worse $\mathrm{NH}_{4}{ }^{+}-\mathrm{N}$ and $\mathrm{PO}_{4}{ }^{3-}-\mathrm{P}$ removal efficiency. Hence, the granules that recovered at $\mathrm{C} / \mathrm{N}$ of 100:10 were most stable with little variation on SVI and good $\mathrm{NH}_{4}{ }^{+}-\mathrm{N}$ as well as $\mathrm{PO}_{4}{ }^{3-}-\mathrm{P}$ removal efficiency after 12 days of reactivation. 


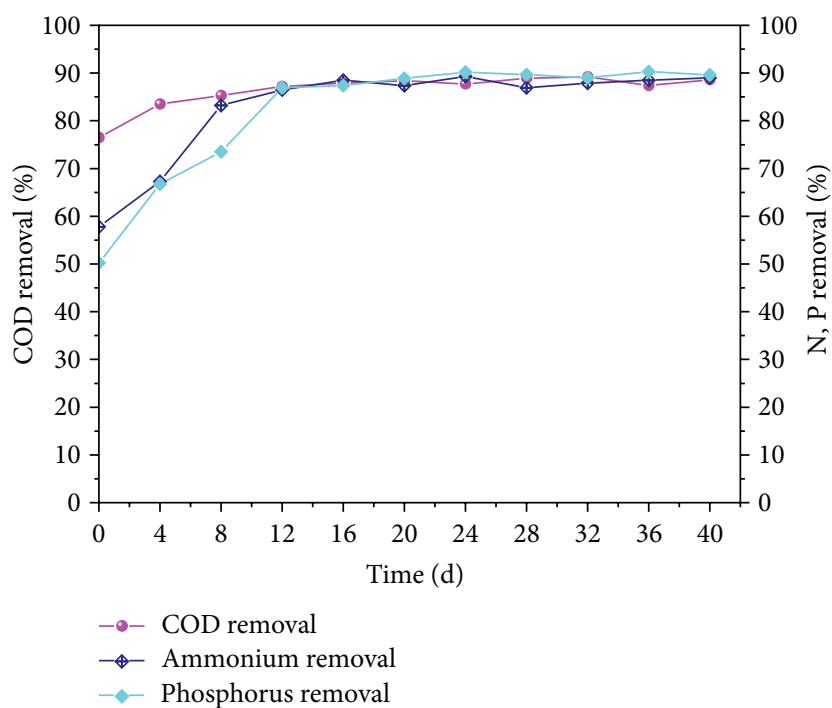

(a)

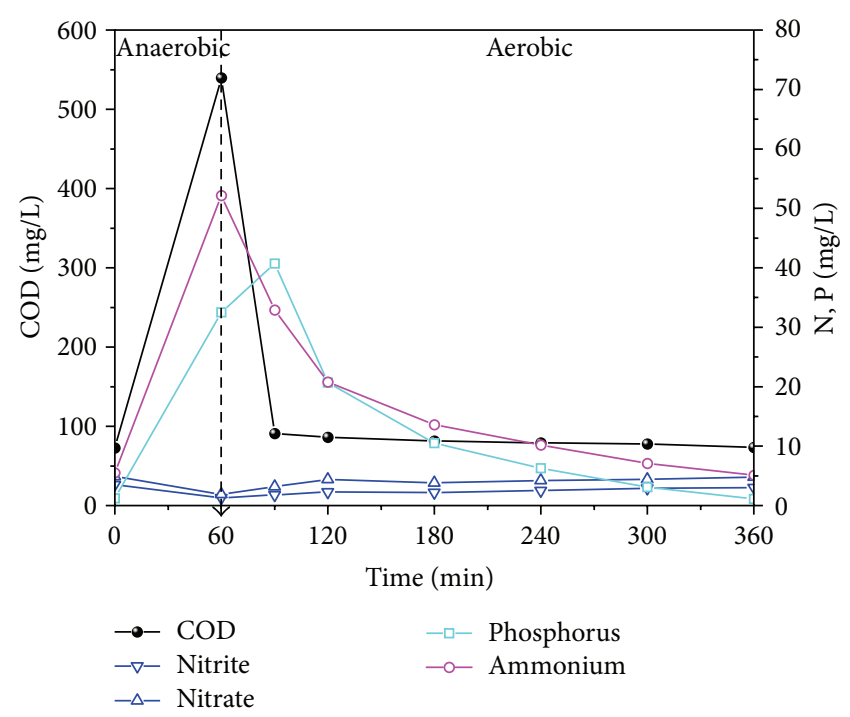

(b)

FIGURE 6: Contaminants removal under optimized operation conditions ((a) process; (b) cycle).

TABLE 2: Effluent characteristics and contaminants removal under different operation conditions.

\begin{tabular}{|c|c|c|c|c|c|c|c|c|c|}
\hline \multicolumn{10}{|c|}{ Effluent } \\
\hline & & $\begin{array}{c}\text { COD } \\
(\mathrm{mg} / \mathrm{L}) \\
\end{array}$ & $\begin{array}{c}\mathrm{NH}_{4}{ }^{+}-\mathrm{N} \\
(\mathrm{mg} / \mathrm{L})\end{array}$ & $\begin{array}{c}\mathrm{NO}_{2}{ }^{-}-\mathrm{N} \\
(\mathrm{mg} / \mathrm{L})\end{array}$ & $\begin{array}{c}\mathrm{NO}_{3}{ }^{-}-\mathrm{N} \\
(\mathrm{mg} / \mathrm{L})\end{array}$ & $\begin{array}{c}\mathrm{PO}_{4}{ }^{3-}-\mathrm{P} \\
(\mathrm{mg} / \mathrm{L})\end{array}$ & $\begin{array}{c}\mathrm{COD}^{\mathrm{a}} \\
(\%)\end{array}$ & $\begin{array}{c}\mathrm{NH}_{4}{ }^{+}-\mathrm{N}^{\mathrm{b}} \\
(\%)\end{array}$ & $\begin{array}{c}\mathrm{PO}_{4}{ }^{3-}-\mathrm{P}^{\mathrm{c}} \\
(\%)\end{array}$ \\
\hline \multirow{4}{*}{$\operatorname{OLR}(\mathrm{g} / \mathrm{L} \cdot \mathrm{d})$} & 2 & $56.0 \pm 5.2$ & $4.4 \pm 0.3$ & $13.3 \pm 0.2$ & - & $8.0 \pm 0.4$ & 89.2 & 89.3 & 52.5 \\
\hline & 4 & $73.8 \pm 6.9$ & $4.4 \pm 0.3$ & $3.1 \pm 0.2$ & - & $3.3 \pm 0.3$ & 89.4 & 90.5 & 80.7 \\
\hline & 8 & $107.8 \pm 8.9$ & $7.6 \pm 0.4$ & $3.5 \pm 0.1$ & $0.5 \pm 0.3$ & $4.1 \pm 0.4$ & 90.5 & 81.3 & 75.9 \\
\hline & 16 & $120.0 \pm 10.3$ & $9.2 \pm 0.4$ & $4.2 \pm 0.2$ & - & $5.2 \pm 0.3$ & 94.4 & 77.0 & 68.9 \\
\hline \multirow{3}{*}{$\mathrm{C} / \mathrm{N}$} & $100: 5$ & $63.0 \pm 6.4$ & $10.1 \pm 0.3$ & $1.8 \pm 0.1$ & $3.3 \pm 0.1$ & $4.7 \pm 0.2$ & 87.9 & 62.4 & 71.3 \\
\hline & $100: 10$ & $58.0 \pm 6.1$ & $3.7 \pm 0.2$ & $1.9 \pm 0.1$ & $3.1 \pm 0.1$ & $4.5 \pm 0.2$ & 88.2 & 89.1 & 72.7 \\
\hline & $100: 20$ & $57.5 \pm 6.5$ & $7.7 \pm 0.3$ & $2.9 \pm 0.1$ & $7.5 \pm 0.5$ & $5.8 \pm 0.3$ & 89.6 & 77.4 & 64.6 \\
\hline
\end{tabular}

a: $\mathrm{COD}$ removal; b: $\mathrm{NH}_{4}{ }^{+}-\mathrm{N}$ removal; $\mathrm{c:} \mathrm{PO}_{4}{ }^{3-}-\mathrm{P}$ removal; -: not detected.

3.3. Quick Recovery of Contaminants Removal. As displayed in Figure 6(a), the bioactivity of AGS progressively revived along with the recovery process under optimized operation conditions. According to the defined conditions previously mentioned, the optimal conditions were as follows: air intensive aeration rate $100 \mathrm{~L} / \mathrm{h}, \mathrm{OLR} 4 \mathrm{~g} / \mathrm{L} \cdot \mathrm{d}$, and $\mathrm{C} / \mathrm{N}$ $100: 10$. Initially $\mathrm{COD}, \mathrm{NH}_{4}{ }^{+}-\mathrm{N}$, and $\mathrm{PO}_{4}{ }^{3-}-\mathrm{P}$ removal was low; however, with the reactivation progress, $\mathrm{COD}, \mathrm{NH}_{4}{ }^{+}$$\mathrm{N}$, and $\mathrm{PO}_{4}{ }^{3-}-\mathrm{P}$ removal kept increasing. After 12 days of reactivation, AGS achieved the best recovery performance on microbial activity; $\mathrm{COD}, \mathrm{NH}_{4}{ }^{+}-\mathrm{N}$, and $\mathrm{PO}_{4}{ }^{3-}$-P removal efficiency could be quickly recovered to $87.2 \%, 86.9 \%$, and $86.5 \%$, respectively.

It is noticeable in Figure 6(b) that $\mathrm{COD}, \mathrm{NH}_{4}{ }^{+}-\mathrm{N}$, and $\mathrm{PO}_{4}{ }^{3-}-\mathrm{P}$ in effluent were $73.5,5.1$, and $1.1 \mathrm{mg} / \mathrm{L}$ in the stable cycle during the reactivation process, and the respective $\mathrm{COD}, \mathrm{NH}_{4}{ }^{+}-\mathrm{N}$, and $\mathrm{PO}_{4}{ }^{3-}-\mathrm{P}$ efficiencies were $86.4 \%, 90.2 \%$, and $93.1 \%$. Moreover, the nitrification and denitrification coefficiency was $75.2 \%$, and the simultaneous nitrification and denitrification rate was $0.41 \mathrm{mmol} / \mathrm{L} \cdot \mathrm{h}$. The results demonstrated that the granules revived under optimal operation conditions gained overall recovery performance. Furthermore, AGS technology could deal with a large number of conversion processes including COD-oxidation, ammonium oxidation, and biological phosphorus removal. The renovation of AGS in store could be successfully utilized as the seed sludge for the rapid start-up of AGS bioreactor.

\section{Conclusions}

The morphology and integrity of AGS were both in good condition after 6 months of storage. Dissolved oxygen had significant impacts on the recovery of the granules, and OLR and $\mathrm{C} / \mathrm{N}$ had comparatively slight influence.

The microstructure of the granules could be sustained; the microbial activity retained good performance; and protein content in EPS was almost unchanged, which demonstrated that air intensive aeration rate of $100 \mathrm{~L} / \mathrm{h}$ was more suitable 
for maintaining its biomass and the structure of AGS. The granules reactivated at OLR of $4 \mathrm{~g} / \mathrm{L} \cdot \mathrm{d}$ could maintain good structural integrity and high contaminants removal efficiency. PS content in EPS was progressively increased which led to the disintegration and worse $\mathrm{NH}_{4}{ }^{+}-\mathrm{N}$ and $\mathrm{PO}_{4}{ }^{3-}-\mathrm{P}$ removal efficiency under higher OLR conditions. Different $\mathrm{C} / \mathrm{N}$ conditions had significant impacts on the settling property of AGS during the reactivation process. High $\mathrm{C} / \mathrm{N}$ resulted in the overgrowth of filamentous bacteria, which presented worse $\mathrm{NH}_{4}{ }^{+}-\mathrm{N}$ and $\mathrm{PO}_{4}{ }^{3-}$-P removal efficiency.

Correspondingly, quick recovery of contaminants removal was accomplished in 12 days at the optimal operation conditions of air intensive aeration rate $100 \mathrm{~L} / \mathrm{h}$, OLR $4 \mathrm{~g} / \mathrm{L} \cdot \mathrm{d}$, and $\mathrm{C} / \mathrm{N} 100: 10$, in which $\mathrm{COD}, \mathrm{NH}_{4}{ }^{+}-\mathrm{N}$, and $\mathrm{PO}_{4}{ }^{3-}$-P removal efficiencies were $87.2 \%, 86.9 \%$ and $86.5 \%$, respectively. The renovation of AGS in store could be successfully utilized as the seed sludge for simplifying the start-up and enhancing the long-term stable operation of AGS bioreactor.

\section{Acknowledgments}

The authors gratefully acknowledge the financial support provided by the State Key Laboratory of Urban Water Resource and Environment (HIT, Grant no. 2013DX12), International Cooperation Program (Grant no. 2010DFA92460), Major Science and Technology Program for Water Pollution Control and Treatment (Grant no. 2012ZX07408001), and National Science Foundation (Grant no. 50978068).

\section{References}

[1] S. S. Adav, D. J. Lee, K. Y. Show, and J. H. Tay, "Aerobic granular sludge: recent advances," Biotechnology Advances, vol. 26, no. 5, pp. 411-423, 2008.

[2] T. Seviour, Z. G. Yuan, M. C. M. van Loosdrecht, and Y. M. Lin, "Aerobic sludge granulation: a tale of two polysaccharides," Water Research, vol. 46, no. 15, pp. 4803-4813, 2012.

[3] M. K. de Kreuk, J. J. Heijnen, and M. C. M. van Loosdrecht, "Simultaneous COD, nitrogen, and phosphate removal by aerobic granular sludge," Biotechnology and Bioengineering, vol. 90, no. 6, pp. 761-769, 2005.

[4] L. L. Liu, Z. P. Wang, J. Yao, X. J. Sun, and W. M. Cai, "Investigation on the properties and kinetics of glucose-fed aerobic granular sludge," Enzyme and Microbial Technology, vol. 36, no. 2-3, pp. 307-313, 2005.

[5] B. Y. P. Moy, J. H. Tay, S. K. Toh et al., "High organic loading influences the physical characteristics of aerobic sludge granules," Letters in Applied Microbiology, vol. 34, no. 6, pp. 407$412,2002$.

[6] H. L. Jiang, S. T. L. Tay, and J. H. Tay, "Changes in structure, activity and metabolism of aerobic granules as a microbial response to high phenol loading," Applied Microbiology and Biotechnology, vol. 63, no. 5, pp. 602-608, 2004.

[7] X. F. Sun, C. Y. Liu, Y. Ma et al., "Enhanced Cu(II) and Cr(VI) biosorption capacity on poly(ethylenimine) grafted aerobic granular sludge," Colloids and Surfaces B, vol. 82, no. 2, pp. 456462, 2011.
[8] H. Xu, Y. Liu, and J. H. Tay, "Effect of $\mathrm{pH}$ on nickel biosorption by aerobic granular sludge," Bioresource Technology, vol. 97, no. 3, pp. 359-363, 2006.

[9] L. M. M. de Bruin, M. K. de Kreuk, H. F. R. van der Roest et al., "Aerobic granular sludge technology: an alternative to activated sludge?" Water Science and Technology, vol. 49, no. 11-12, pp. 1-9, 2004.

[10] Y. Liu and J. H. Tay, “The essential role of hydrodynamic shear force in the formation of biofilm and granular sludge," Water Research, vol. 36, no. 7, pp. 1653-1665, 2002.

[11] B. S. McSwain, R. L. Irvine, M. Hausner, and P. A. Wilderer, "Composition and distribution of extracellular polymeric substances in aerobic flocs and granular sludge," Applied and Environmental Microbiology, vol. 71, no. 2, pp. 1051-1057, 2005.

[12] S. Wang, W. X. Shi, S. L. Yu et al., "Formation of aerobic granules by $\mathrm{Mg}^{2+}$ and $\mathrm{Al}^{3+}$ augmentation in sequencing batch airlift reactor at low temperature," Bioprocess and Biosystems Engineering, vol. 35, no. 7, pp. 1049-1055, 2012.

[13] D. W. Gao, X. J. Yuan, and H. Liang, "Reactivation performance of aerobic granules under different storage strategies," Water Research, vol. 46, no. 10, pp. 3315-3322, 2012.

[14] R. L. Bao, S. L. Yu, W. X. Shi, X. Zhang, and Y. Wang, "Aerobic granules formation and nutrients removal characteristics in sequencing batch airlift reactor (SBAR) at low temperature," Journal of Hazardous Materials, vol. 168, no. 2-3, pp. 1334-1340, 2009.

[15] G. J. F. Smolders, J. M. Klop, M. C. M. van Loosdrecht, and J. J. Heijnen, "A metabolic model of the biological phosphorus removal process. I. Effect of the sludge retention time," Biotechnology and Bioengineering, vol. 48, no. 3, pp. 222-233, 1995.

[16] APHA, Standard Methods for the Examination of Water and Wastewater, American Public Health Association, Washington, DC, USA, 20th edition, 1998.

[17] A. Laguna, A. Ouattara, R. O. Gonzalez et al., "A simple and low cost technique for determining the granulometry of upflow anaerobic sludge blanket reactor sludge," Water Science and Technology, vol. 40, no. 8, pp. 1-8, 1999.

[18] N. Schwarzenbeck, R. Erley, and P. A. Wilderer, "Aerobic granular sludge in an SBR-system treating wastewater rich in particulate matter," Water Science and Technology, vol. 49, no. 11-12, pp. 41-46, 2004.

[19] M. Dubois, K. A. Gilles, J. K. Hamilton, P. A. Rebers, and F. Smith, "Colorimetric method for determination of sugars and related substances," Analytical Chemistry, vol. 28, no. 3, pp. 350356, 1956.

[20] O. H. Lowry, N. J. Rosebrough, A. L. Farr, and R. J. Randall, "Protein measurement with the folin phenol reagent," The Journal of Biological Chemistry, vol. 193, no. 1, pp. 265-275, 1951.

[21] S. T. L. Tay, V. Ivanov, S. Yi, W. Q. Zhuang, and J. H. Tay, "Presence of anaerobic Bacteroides in aerobically grown microbial granules," Microbial Ecology, vol. 44, no. 3, pp. 278$285,2002$.

[22] Y. Q. Liu, Y. Liu, and J. H. Tay, "The effects of extracellular polymeric substances on the formation and stability of biogranules," Applied Microbiology and Biotechnology, vol. 65, no. 2, pp. 143148, 2004.

[23] S. S. Adav, D. J. Lee, and J. Y. Lai, "Effects of aeration intensity on formation of phenol-fed aerobic granules and extracellular polymeric substances," Applied Microbiology and Biotechnology, vol. 77, no. 1, pp. 175-182, 2007. 
[24] S. Wang, W. X. Shi, S. L. Yu, and X. S. Yi, "Rapid cultivation of aerobic granular sludge by bone glue augmentation and contaminant removal characteristics," Water Science and Technology, vol. 67, no. 7, pp. 1627-1633, 2013.

[25] L. Tijhuis, M. C. M. van Loosdrecht, and J. J. Heijnen, "Formation and growth of heterotrophic aerobic biofilms on small suspended particles in airlift reactors," Biotechnology and Bioengineering, vol. 44, no. 5, pp. 595-608, 1994.

[26] A. Mosquera-Corral, M. K. de Kreuk, J. J. Heijnen, and M. C. M. van Loosdrecht, "Effects of oxygen concentration on N-removal in an aerobic granular sludge reactor," Water Research, vol. 39, no. 12, pp. 2676-2686, 2005.

[27] Y. M. Lin, Y. Liu, and J. H. Tay, "Development and characteristics of phosphorus-accumulating microbial granules in sequencing batch reactors," Applied Microbiology and Biotechnology, vol. 62, no. 4, pp. 430-435, 2003.

[28] J. W. Costerton, R. T. Irvin, and K. J. Cheng, "The bacterial glycocalyx in nature and disease," Annual Review of Microbiology, vol. 35, pp. 299-324, 1981.

[29] J. H. Tay, Q. S. Liu, and Y. Liu, "The role of cellular polysaccharides in the formation and stability of aerobic granules," Letters in Applied Microbiology, vol. 33, no. 3, pp. 222-226, 2001.

[30] M. K. de Kreuk, M. Pronk, and M. C. M. van Loosdrecht, "Formation of aerobic granules and conversion processes in an aerobic granular sludge reactor at moderate and low temperatures," Water Research, vol. 39, no. 18, pp. 4476-4484, 2005.

[31] Y. M. Zheng, H. Q. Yu, S. J. Liu, and X. Z. Liu, "Formation and instability of aerobic granules under high organic loading conditions," Chemosphere, vol. 63, no. 10, pp. 1791-1800, 2006.

[32] C. M. López Vázquez, C. M. Hooijmans, D. Brdjanovic, H. J. Gijzen, and M. C. M. van Loosdrecht, "Factors affecting the microbial populations at full-scale enhanced biological phosphorus removal (EBPR) wastewater treatment plants in The Netherlands," Water Research, vol. 42, no. 10-11, pp. 23492360, 2008. 

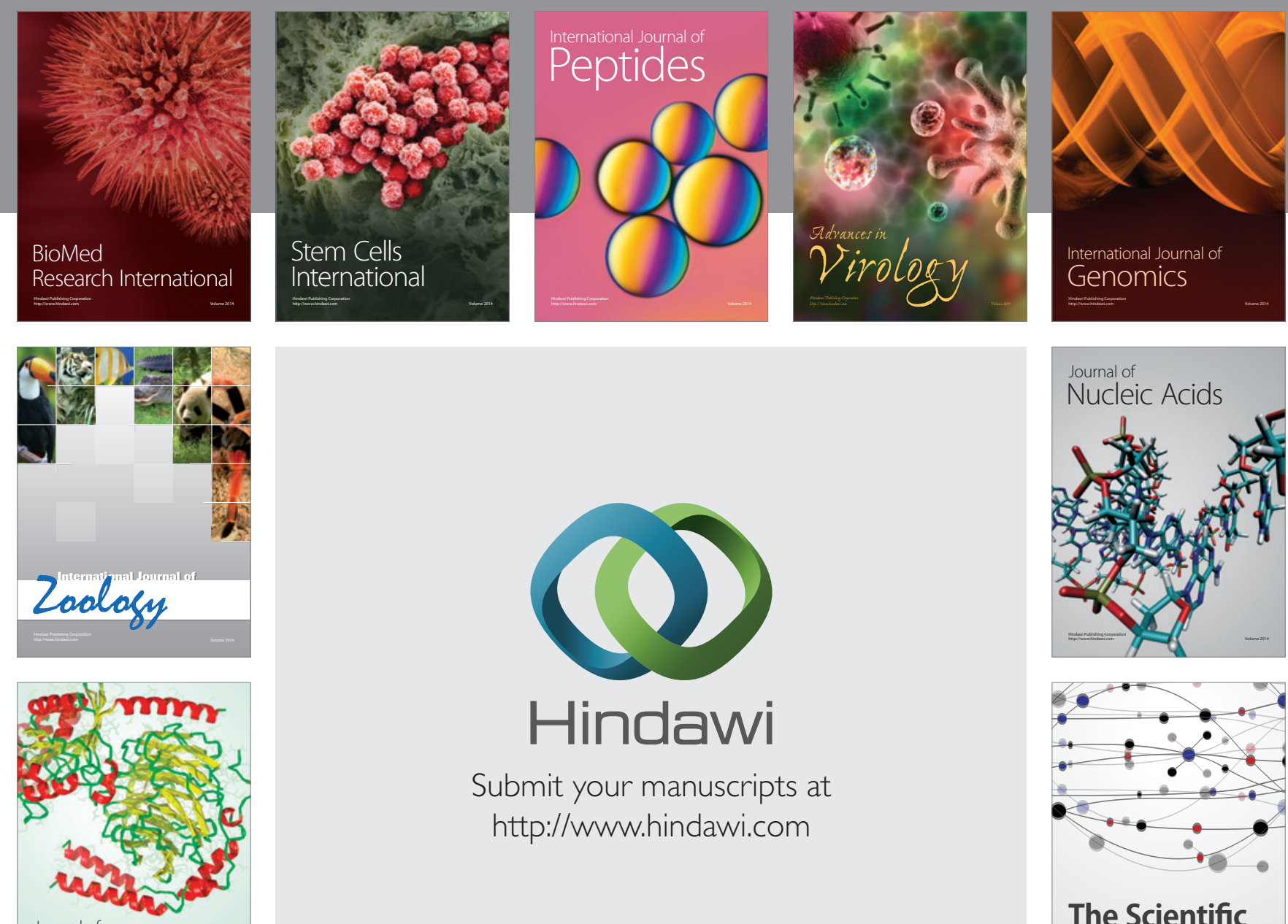

Submit your manuscripts at

http://www.hindawi.com

Journal of
Signal Transduction
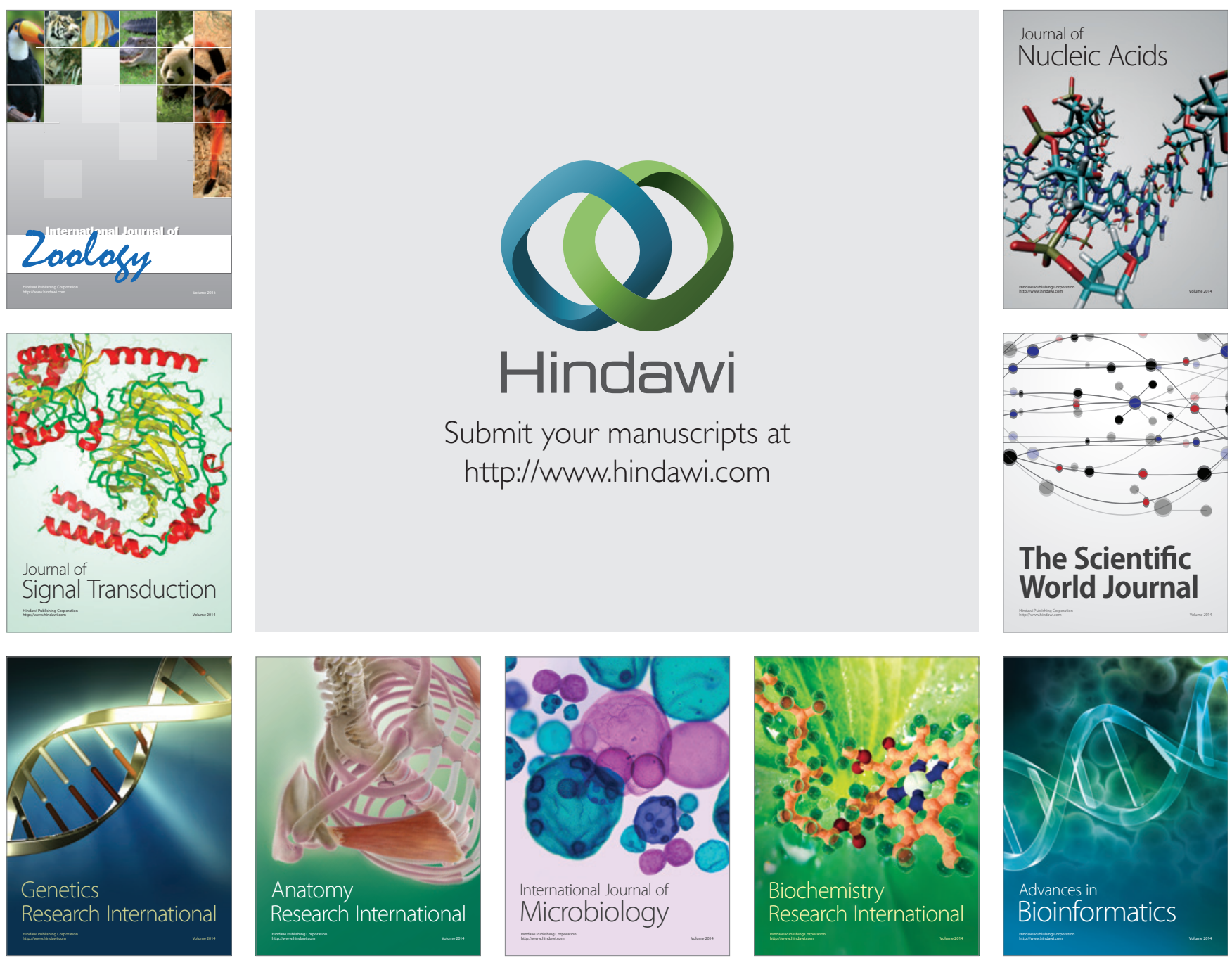

The Scientific World Journal
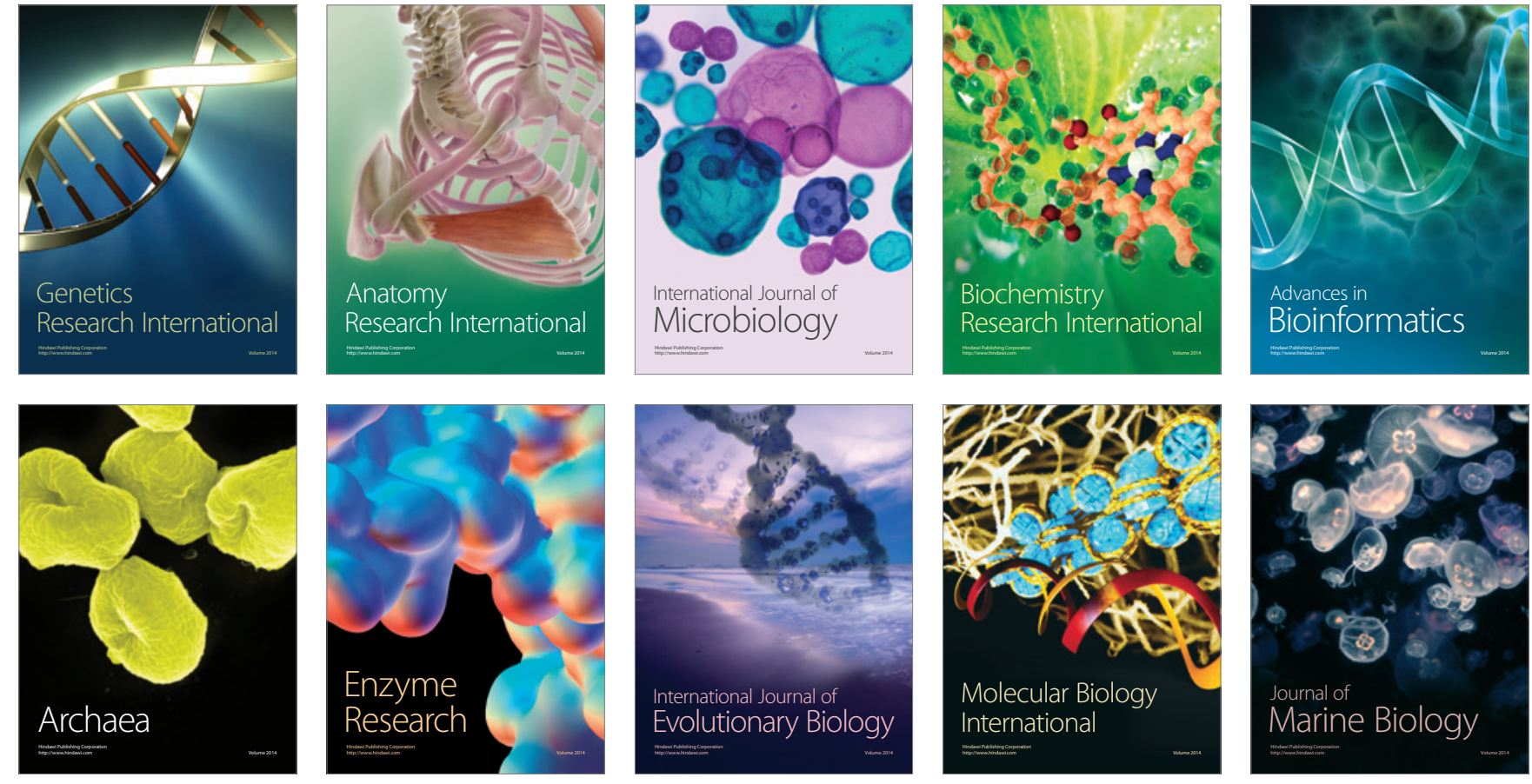